研 究 論 交

\title{
非破壊試験の信頼性を考慮した検查後の 溶接品質とその支配因子*
}

一建築鉄骨溶接部の例一

\author{
传藤 邦彦** 對田 政男** 南 二三吉**
}

藤 盛紀明***中辻照幸***

\section{Reliability of Inspected Welds Taking Defect Detectability of NDT into Account and Influence Factors to Reliability of Welds* \\ -An Application for Welded Steel Framed Structure-}

by Kunihiko Satoh**, Masao Toyoda**, Fumiyoshi Minami**

Toshiaki Fujimori*** and Teruyuki Nakatsuii***

NDT, in general, is performed for quality assuarance of welds. The reliability of welds, however, is affected by the defect detectability of NDT or the other inspection factors. In the present paper, an analysis method for getting the reliability of inspected welds is declared, and the controlling factors of the reliability of welds are discussed.

The reliability of welds is decided by correlation of the defect detectability of NDT and critical defect level for repair. According to the defect detectability of NDT, therefore, critical defect level for repair $\mathrm{A}_{c r}$ should be set smaller than critical allowable defect size $a_{c r}$.

Deteriorating the defect detectability of NDT, the reliability of welds deteriorates. And the degree of deterioration of reliability depends on the sensitivity factor $a_{0}$ and on the accuracy factor $\sigma_{A}$, but if $a_{0}$ or $\sigma_{A}$ is much smaller than $a_{c r}$, improvement of NDT detectability does not always increase the reliability of welds. It is necessary to select the inspection procedure according to $a_{c r}$ for QA of welds.

In sampling inspection, the reliability of welds $R$ is decided definitely according to average sampling ratio $\bar{p}_{s}$, and $R-\bar{p}_{s}$ is in linear relationship. If the highly defective joints exist, the reliability of welds increases by performing sampling inspection with emphasis on those joints.

\section{1. 緒言}

溶接部の使用性能を確保するためには, 構造物や構造 要素の破損をむたらすような欠陷を排除することが必要 となる，そのためには，性能低下を招く欠陷の適確な把 握と排除すべき欠陥の限界評価の確立が重要である. 欠 陷の検出は非破壊検查によるのが普通であるから，溶接 部の品質は非破壊検查に起因する諸因子の影響を受ける のは当然である.

\footnotetext{
*原稿受付 昭和55年 2 月 7 日（昭和54年 5 月 第55回WD分科会にて辇 表)

**正 員 大阪大学工学部 Member, Faculty of Engineering, Osaka University

***正 員 清水建設(株)研究所 Member, SHIMIZU Construc. tion Co., Ltd
}

非破壊検查においては，必ずしむ欠陷の状態が正確に 把握されるわりではない，すなわち，次陷検出能力とい う非破壊試験のもつ信頼性の存在が検査後の溶接品質に 影響を与える ${ }^{1,2)}$.また，非破壊検查で通常採用されてい る抜取り検查などは同じく確率的要因であり, 溶接品質 の支配因子となろう。このような現状を考虑するとき， 検查後の溶接品質は非破壊試験の欠陷指示寸法の情報の みから判断できないととがわかる. 更化陥指示寸法に 対する採否許容限界性性能面加らの欠陌の許容限界之は 異なるものであるととが予想される。

本報告では，乙の点に注目し，非破壊試験の欠陷検出 能力を考虑した検查後の溶接品罆に関して解析的, 数値 実験的考察を行う。そこで，溶接部の品質と非破壊試験 
との関係の把握の仕方の基本的な考光方と，その品質へ の諸因子の影瓣を考察するために，ここでは，とくに骨 組構造物で用いられる超望波探賃試験を例にとって具体 的な解析例を示す。

\section{2. 超音波探傷試験の欠陥検出能力}

非破壊試験の信頼性（欠陥検出能力）には，1）准が 試験によって検出され得るかを表す検出確率，と，2）検 出された欠陷の指示寸法の実寸法に対する精度，の2つ が考えられる．非破壊試験の信頼性の検討は，従来実験 室的なむのが多く3.4), 現実使用されている試験法に関 するデータは皆無といってよい，その信頼性は，非破壞 試験に用いる装置, 検查員, 欠陥の判定方法, 対象欠僱 の種類などの多くの因子に起因する，例えぼ Packman ${ }^{3)}$ や Herr, Marsh') などが検出能力や Human Error 亿関 する調査を行った例があるが，その一般的傾向はなかな かつかみにくいのが実情である.

著者らは，別報に詳細を述べるように，建築鉄骨の現 場溶接に用いられる超音波探甥試験を取り上げ，現行建 築学会基準によった場合の超音波探賃試験の欠陥検出能 力について検討した ${ }^{5}$. Figs. 1，2 は, その恰出確率, 精 度に関する結果の代表例を示したものである．Fig. 1 は， 2 つの超高層ビルを対象に, 手動探傷の欠陷検出率につ いて調査した結果を示したものである.すなわち，同一 継手に対して自動探傷之手動探倁を商用し，両者で発見 された欠陥の和集合を $100 \%$ と仮定して手動探賃による 欠陷湌出率を求めたすのである。自動探傷，手動探傷で 100\%の欠陥が必ずし屯発見できるわけではないが,従来 の研究結果3,4)などす考慮すると建築学会基準の手動探 傷では，Fig. 1 亿示す検出確率に近い屯のを有している と判断される，すなわち，長さ $a$ の実欠陷が発見され る確率 $D(a)$ は，

$$
D(a)=\left(1-a_{0} / a\right)^{r} \quad\left(a \geq a_{0}\right)
$$

と表わされ，骨組構造物現場溶接では $a_{0}=5 \mathrm{~mm}, \gamma=1$ 程度とみなせる。

一方，Fig. 2 は人工的に欠陷を含む溶接部を作成し， それに刘して検查員，検查回数などを变えて得た指示長 さのばらつきと実寸法を示した代表例である．今回の調 楂では, 欠宿指示長さの平均值はほ洁実欠陷寸法之対応 している、また試験のばらつきは欠陷の種類に依存し， 割れ状の欠陥では, そのばらつきの標準偏差 $\sigma_{A}$ は3 $\mathrm{mm}$ 程度である. Fig. 2 加らあわかるように, 実寸法 $a$ のあのを $A$ の大きさと判断する確率密度 $f(A / a)$ は活 ほ正規尔布》汇近く，

$$
f(A / a)=\frac{1}{\sqrt{2 \pi}} \frac{1}{\sqrt{\sigma_{A}}} \exp \left\{-\frac{(A-a)^{2}}{2 \sigma_{A}^{2}}\right\} \cdots \cdots \cdots(2)
$$

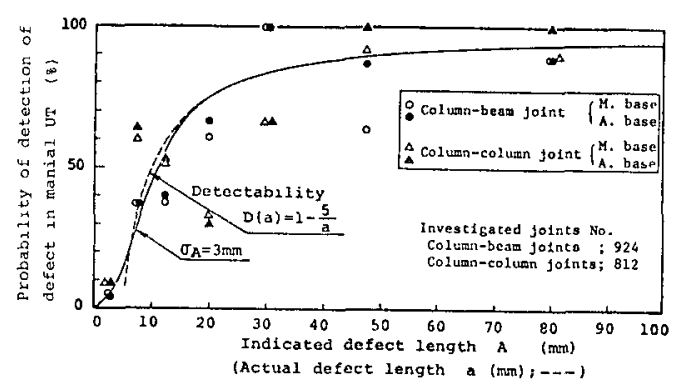

Fig. 1 Probability of detection of defect by ultrasonic examination
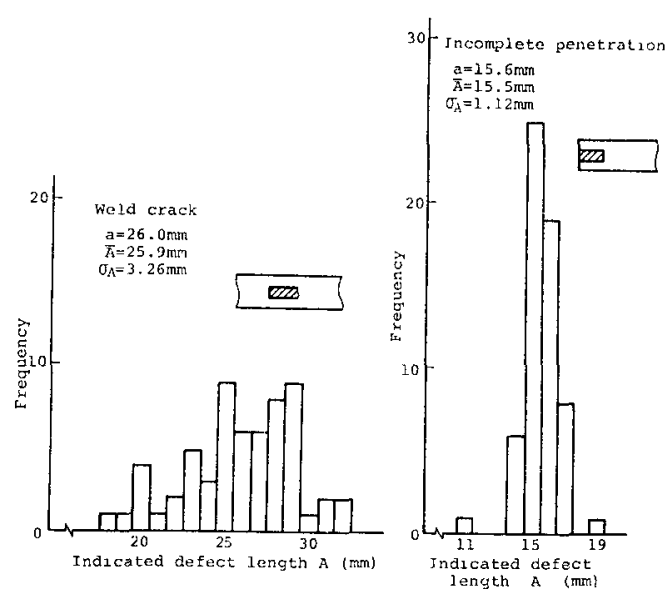

Fig. 2 Accuracy of measuring the length of defects by ultrasonic examination

と表され， $\sigma_{\Delta} \approx 3 \mathrm{~mm}$ と見ればよいようである.

以下の具体的解析に拈いては，検出能力は(1)，(2)を基 準とし, 更に超音波探傷の検出能力は今回の調查の結果 を代表例として用いる．なお，他の検查手法を用いる場 合には，当然ここで用いるものと定量的に異なることに 注意しなければならない。

\section{3. 非破壊試験の欠宿検出能力を考虑した検査 後の溶接部の信頼性}

\section{1 検查後の溶接部の信頼性}

いま, 㩐造物の使用要求性能の見地から溶接部に許容 される欠陷寸法が明らかにされており，その最大欠陷代

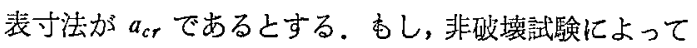
すべての久陥が実体どおりに把握されるのならは， $a_{c r}$ を超える寸法の欠陷に対して補修を行うことによって， 溶接部は性能面から100\%の信頼性が得られるととにな る.しかし，現実には非破罗試験には一定の欠宿桧出能 力があり，また，抜取り検查などの手法がとられるた め，必ずしも信頼性は100\%とはいえない，本論文では， 
いくつかの溶接部をすつ構造物において, 限界寸法 $a_{c r}$ は既に与えられているとし，その棈造物の検査後の溶接 部の信頼性 $R$ を

$$
\begin{gathered}
R=\text { 検查後に } a_{c r} \text { を超える寸法の } \\
\text { 久陷が残存しない確率 }
\end{gathered}
$$

\section{と定義する。}

一般には，一定の検出能力（ $D(a), f(A / a)$ など）を もつ非破壞試験が一定の技取り率 $p_{s}$ でもって適用され， 陚験で指示された欠陷寸法に対して一定の採否（補修） 限界寸法 $A_{c r}$ を超える久陥について補修されるという 検查体制がとられている．乙の場合の検查後の信頼性 $R$ は, むしその構造物の溶接部敒発生する久陥の実寸法 $a$ に対する確率密度 $p(a)$ がわかっているならば, 確率論 的解析手法あるいはモンテカルロ法による数值実験的シ ミュレーション手法などによって求めるてとができる. 解析的手法似よると， $R$ の值は，1 加ら $a_{c r}$ 以上の寸 法の欠陥が残存する割合を引いたもので求められ，ての $a_{c r}$ 以上の残存久陥率は，非破壊試験によって $a_{c r}$ 以上 だけれどあ発見できなかったものと，arr 以上だけれど 屯 $A_{c r}$ 以下の寸法之判断してしまったものの和で与え られるので, 結局

$$
R=1-\int_{a_{c r}}^{\infty} p(a)\left[1-p_{s} \cdot D(a) \cdot \int_{A_{c r}}^{\infty} f(A / a) d A\right] d a
$$

で与えられる。また，Fig. 3 は検查シミュレーションの 手順を示したもので，(4)式は，検查刘像が数多くある場 合に対応するのに対して, シミュレーションによれば有 限の検查対象に対する結果のばらつきなどが把握でき る。

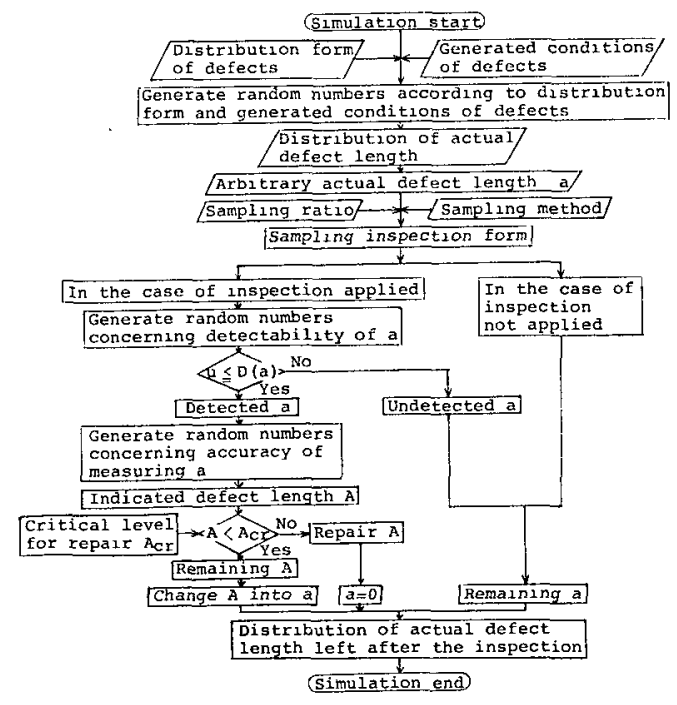

Fig. 3 Flow chart of sampling inspection considering the reliability of ultrasonic examination

\section{2 実欠宿寸法分布の推定}

前項のように検查後の溶接部の信頼性 $R$ を求めるに はその棈造物の欠陷の策寸法分布関数 $p(a)$ を明らかに しておく必要がある。しかし，見実の非破壊検查で得ら れる情報は欠宿指示寸法分布である。いま，適用される 非破壊試験の信頼性がわかっていれば，従来の同種構造 物の久宿指示寸法分布加ら，Fig. 4 亿示す手順に上って 実欠陷寸法分布の密度関数 $p(a)$ 加推定できる.

例元ば，Fig. 5 はある超高層ビル（20階， $\mathrm{S}$ 造）の鉄 骨現場溶接におりる久陥指示寸法分布を示したあのであ り，Fig.6(a) は，乙れを用いて前述の超音波探傷の検出 確率と拔取り率を考虑して求めた実欠陷寸法分布を示し てある。乙の場合 $p(a)$ は，

$$
p(a)=\lambda m a^{m-1} e^{-\lambda a^{m}}
$$

なる 2 母数 Weibull 分布》 と仮想し， $\lambda, m$ を決定し た.

Fig. 6(b)，(c) は，乙の実欠宿寸法分布を用いて検查過 程をシミュレートして得られた欠陷指示寸法分布(実線) 之残存欠陷寸法分布であり，乙の場合には一例として

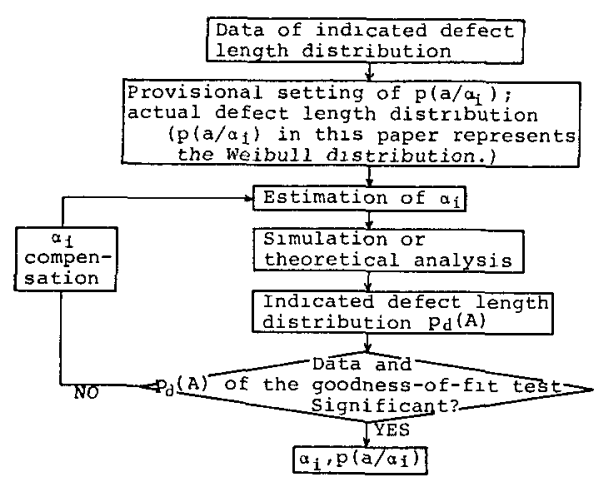

Fig. 4 Procedure for estimating actual defect length distribution

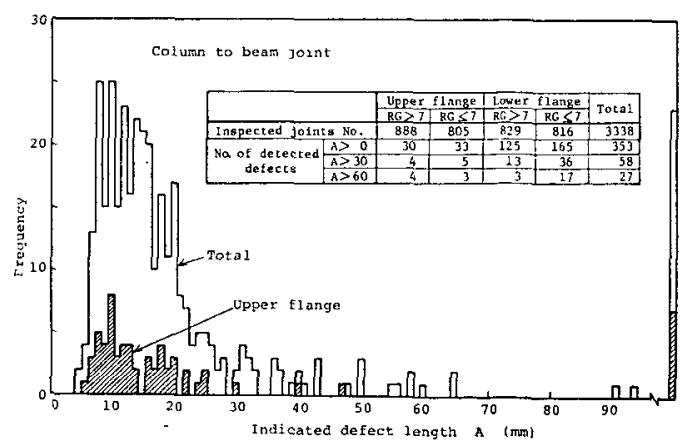

Fig. 5 An example of the indicated defect length distribution obtained from field welding in a steel building construction 

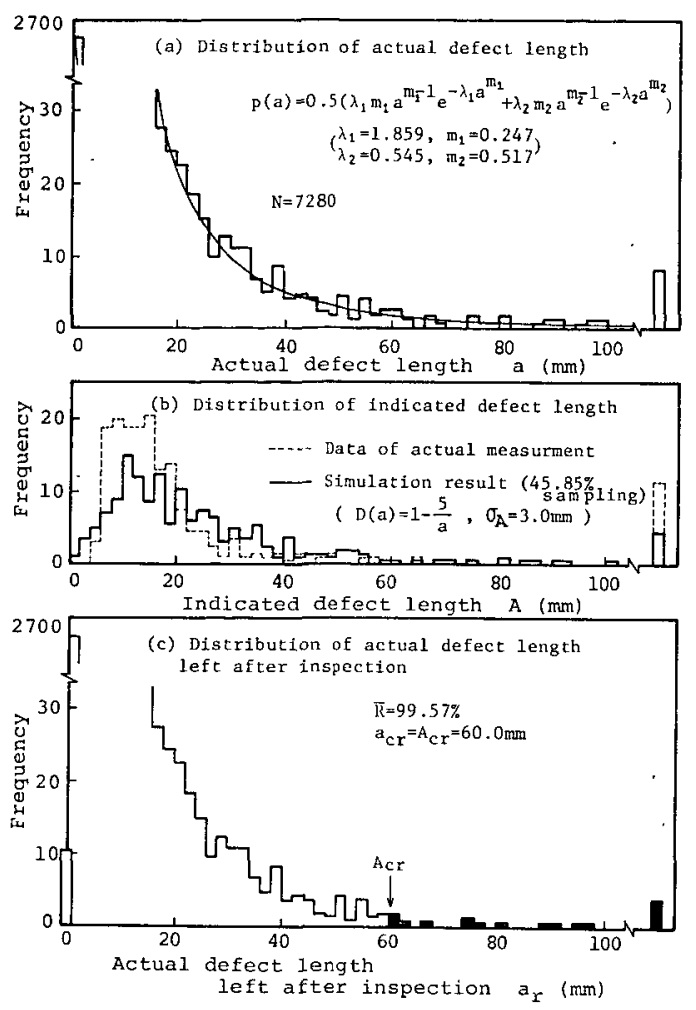

Fig. 6 Results of the simulation concerning the reliability of welds

$A_{c r}=a_{c r}=60 \mathrm{~mm}$ と設定した．乙の $a_{c r}$ の值は，超高層 ビルの設計設定条件加ら従来の著者らの研究結果6)を屯 とに計算した值である.（c）図における塗りつぶした $a_{r} \geqq a_{c r}$ なる久宿の残存確率は破損確率 $f$ を表してお b，信頼性 $R$ は $R=1-f$ から求められる. この構造で は本シミュレーション結果によると平均信頼性 $\mathbb{R} は$ $99.57 \%$ と求まる。

このような検查後の溶接部の信頼性は, 非破壊試験の 検出能力, 補修限界 $A_{c r}$, 拔取り率 $p_{s}$ などの諸支配因 子の影響を受けるはずであり，次に諸因子の影響につい て考察する.

\section{4. 検査後の溶接品質に及ぼす諸因子の影響}

非破壊㭘查後の溶接品質（信頼性）を支配する主な因 子は，(a) 検查対象数 $N$, (b) 補修限界寸法 $A_{c r}$, (c) 抜取 り率 $p_{s}$, 及び，技取り手法，(d) 非破壤試験の检出確率 指数 $a_{0}$ in $D(a)$, (e) 非破壊試験の検出精度指数 $\sigma_{A}$ in $f$ (A/a) などがある.とれらの因子の影響について，Fig. 6 の実欠陷寸法分在之建築鉄骨の超音波探甥試験立対象 として検討した結果を示す，なお，以下では $a_{c r}$ は既に 与えられたすのと考え，ととでは主に $a_{c r}=60 \mathrm{~mm}$ とし

\section{て解析してある。}

Fig. 7 は，検查対象数 $N$ が信頼性 $R$ に及ぼす影響を 示したすので，実線はシミュレーションによって得られ る $R$ の平均を鎖線は $R$ のばらつきを考えた95\%信頼下 限である. 図のように $N$ が多いとぱらつきあ小さく解 析的手法 $(N=\infty)$ に近づくが， $N$ が少なくなるにつれ て，R の信頼下限は低くなり，検查対象個数が少なけれ ばそれだけ溶接品質が悪くなることああることを示して いる。

Fig. 8 は, シミュレーションより求められる一定の検 出能力をすつ非破壊試験を適用したときの設定補修限界 $A_{\text {cr }}$ と溶接部の信頼性 $R$ の関係を示したものである. 補修限界 $A_{c r}$ をその構造物の欠陥許容限界 $a_{c r}$ より李 小さく設定すれば， $R$ の值は大きくなり，溶接品質驾向 上する．同時にこの $R-A_{c r}$ 関係は，ある程度 $A_{c r}$ を

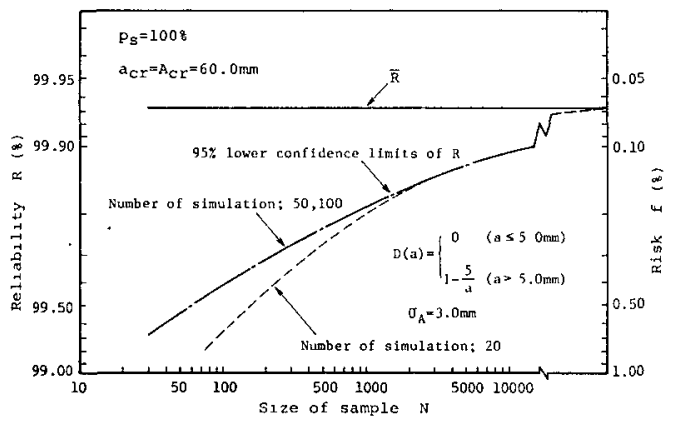

Fig. 7 Effect of the size of sample on the reliability of welds

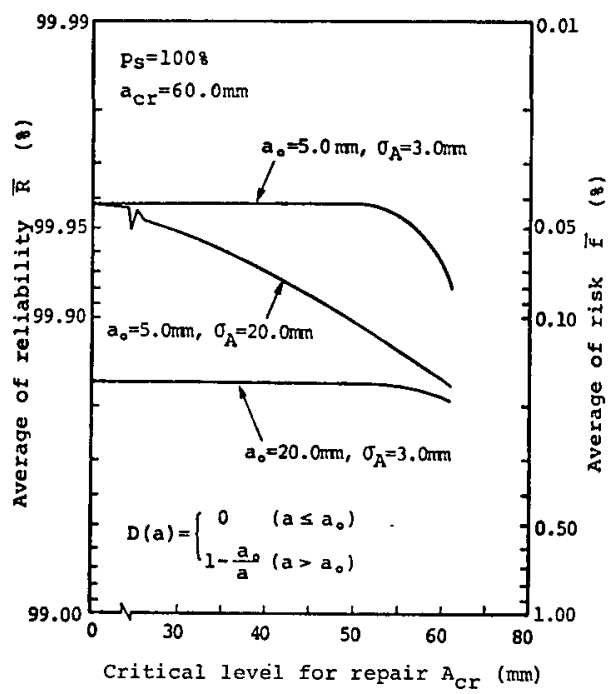

Fig. 8 Relation between critical level for repair and the reliability of welds 


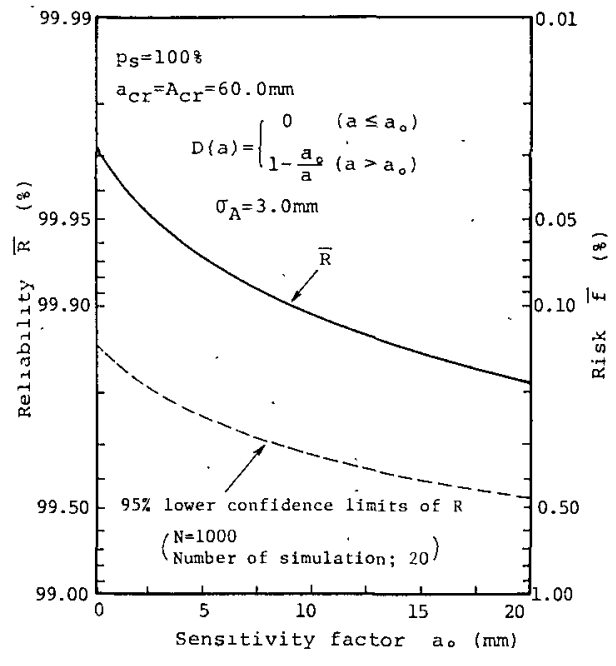

(a)

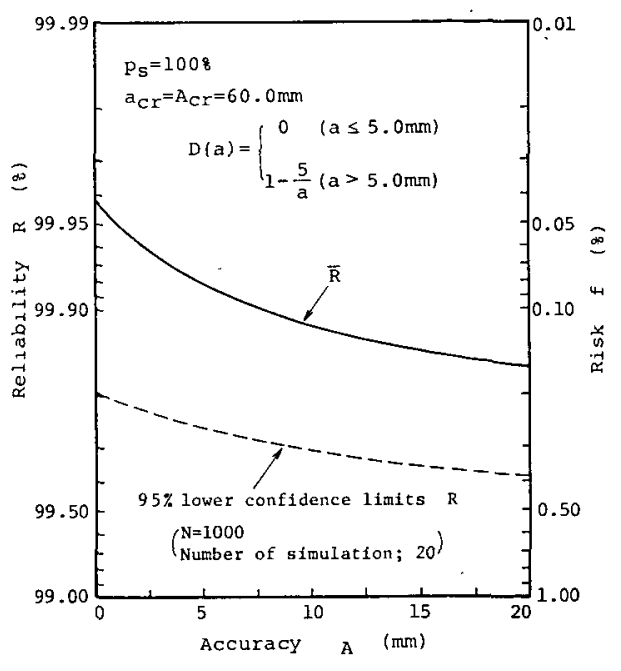

(b)

Fig. 9 Effect of the defect detectability of NDT on the reliability of welds

小さくすれば，それ以上 $A_{c r}$ を小さく設定してす $R$ は ほとんど変化しなくなり，溶接品質の向上は望的ないて とを示している. そのようなほぼ一定の $R$ を示す $A_{c r}$ の值は非破燷試験の検出精度の影響が大きいととが図か らうかがえる.いずれにしてす溶接品質の点から非破壊 試験が一定の検出能力をあつ場合, 補修限界 $A_{c r}$ を $a_{c r}$ よりあ小さく設定する必要性が示唆されている.

Fig. 9 は, 非破壊試験の欠宿㭘出能力が信頼性 $R$ 亿及 ぼす影響を示したもので, 当然ながら久陥検出能力が悪 くなると，すなわち $a_{0}$ や $\sigma_{A}$ が大きくなると信頼性 $R$ は低下する．しかし，次報佯述するように $a_{0}$ が大き くなる場合と $\sigma_{A}$ が大きくなる場合では $R$ の低下をむ たらす原因が異なり， $a_{0}$ が大きくなると $a>a_{c r}$ の欠陥 を発見するととができず見逃すととによって $R$ が低下 するのに対して， $\sigma_{A}$ が大きくなると $a>a_{c r}$ の欠陷を $A<A_{c r}$ と過小評価して補修しないととによって $R$ が 低下する。

一般には抜取り検查が採用される場合が多いが，抜取 り率 $p_{s}$ が定まると，(4)式から

$$
R=1-\int_{a_{c r}}^{\infty} p(a) d a+p_{s} \int_{a_{c r}}^{\infty} p(a) \cdot D(a) \cdot \int_{A_{c r}}^{\infty} f(A / a) d a
$$

となり，検查対象，試験方法が一定の場合

$$
R=(1-k)+p_{s} k_{1}
$$

の形となって，R と $p_{s}$ は線形関係䎲ある。とてで $k$, $k_{1}$ は実久陥分布, 非破壊試験の信賴性, $A_{c r}$ 亿依存す る量である. $k_{1}$ の值は $R-p_{s}$ 関係の傾きを示し, $A_{c r} /$ $a_{c r}, a_{0} / a_{c r}, \sigma_{A} / a_{c r}$ が小さくなるほど大きくなる。乙
Table I Relation between the defect rate and the weld conditions in steel building constructions (Column-beam welded joints)

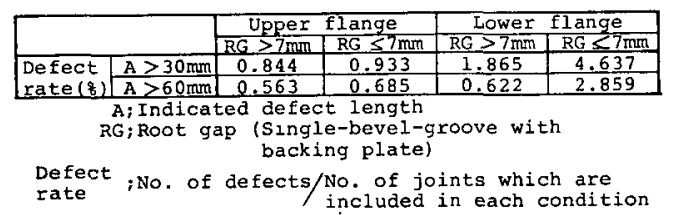

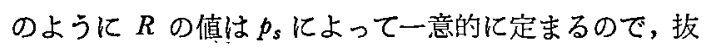
取り率のみを指定するような手法（補修は検查不合格部 のみ）によって溶接品質の十分な確保がなされるとは限 らない。

ところで, 久陷の発生確率は溶接諸条件に伐存してい る場合が多い. Table 1 は超高層ビル 2 例（5449検査個 所）を例にとって柱・梁接合部の現場溶接での大きな欠 陷発生状況を・下フランジ別とルート間隔 $7 \mathrm{~mm}$ 以上 と以下の 4 組合せの場合について示したものである。乙 の表から鉄骨現場溶接では下フランジでルート間隔 ? $\mathrm{mm}$ 以下の場合は他の場合よりす欠陷発生率が高いとと がわかる。このような久俻の高発生確率部が溶接諸条件 との関係でわかっている場合には，その場所を選択的に 拔取るととは非破壊検查上有利と予想される。Fig.10は 上記 4 組合せのうち，下フランジ・ルート間隔 $7 \mathrm{~mm}$ 以 下の場合のみを他の場合に比べて $S$ 倍だけ余分に抜取。 たときの検查後の溶接部の信頼性 $R$ と平均抜取り率 $\bar{p}_{s}$ との関係を示したあのである.このような高発生確率部 選択拔取り手法を採用すると同一の平均抜取り率であっ 


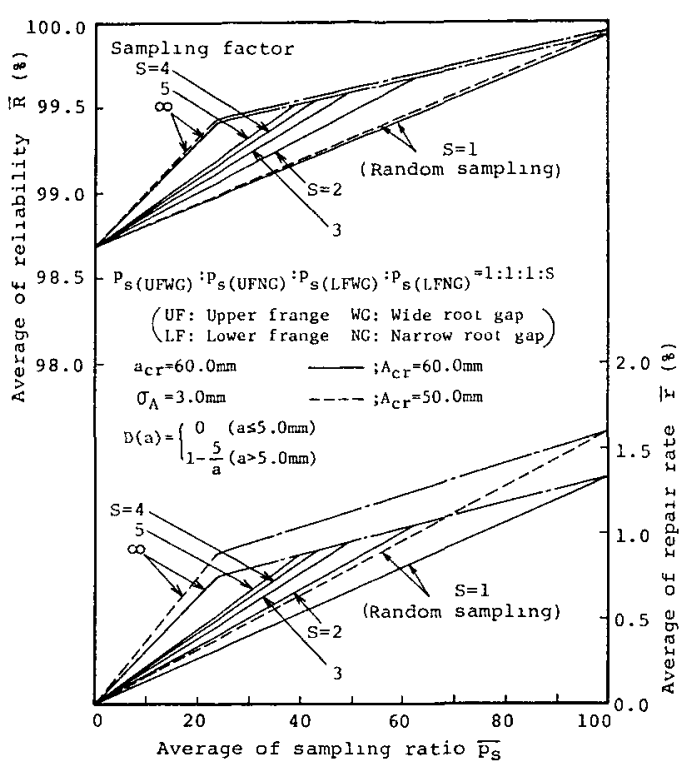

Fig. 10 Relation between the sampling ratio and the reliability when examination applied with emphasis on the joints where defects occur more frequently

ても, Random sampling の場合に比べてより大きな信 頼性 $R$ が得られ，乙の場合 $S$ を大きくとるほど $R$ が大 きくなる.

抜取り検查の採用に対しては，とのような欠宿発生と 溶接諸条件の関係を把握し，拔取り手法の合理化を図る ことが必要である.

\section{5. 結論}

非破髙試験の欠陷检出能力を考虑した検查後の溶接品 質（溶接部の信頼性）の解析手法の具体化を試み，次の ような結論を得た。

（1）非破壊検査後の溶接品質は，非破壊試験の欠陷検 出能力と補修限界の設定の相互効果によって決まる。そ して非破壊試験の検出能力に応して, 補修限界は要求性 能加ら定まる欠陷の許容限界 $a_{c r}$ よりあ小さく設定する 必要性が指摘された。
（2）非破壊試験の久陷検出能力が低下すると，一定の 検查手法のむとでは溶接品質 $R$ の低下をあたらす傾向 がある，その低下の程度は, 検出確率指数 $a_{0}$ や精度指 数 $\sigma_{A}$ 亿依存するが， $a_{0} や \sigma_{A}$ が $a_{c r}$ に比へて小さな 箕围では検出能力の增強が必ずしも大きな溶接品質の向 上をむたらすとは限らない，椡容限界 $a_{c r}$ に見合った検 查手法の選定が必要となる。

(3) 投取り検查では, 溶接品質 $R$ は構造物の平均抜

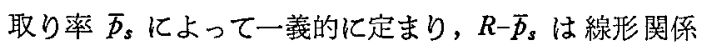
にある.したがって，単純抜取りは信頼性の点からはあ まり意味がない，溶接諸条件と欠陥の発生確率との間に 相関が認められる場合には，商発生確率部選択拔取りは 信頼性 $R$ の向上の点加ら意味がある.

なお，本諭文では具体例を示す意味において建築鉄骨 溶接部を例にとり, 超音波探賃試験を対象として取り上 げた．またての場合, 性能面からの主たる考慮対象欠陥 は平面状欠陥である。一般には対象構造物によって，主 たる保泟性能が異なるし，適用される非破壊試験法も種 種のあのが考えられる．とのような場合には定量的には ここでの結果がただちに適用されないが，溶接部の品質 の考え方は全く同じであり，同様な考察のもとにより高 い品質を得る努力が必要となる。

\section{文献}

1）板垣 浩, 尾筒交夫，根本知明：棈造物中の欠陷分布推定に閉与 る一考察, 日本造船学会馀交集, 139 (1976)，292

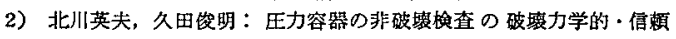
性工学的被価方法, 欧力技術, 17 (1979)，46

3) Packman, R.F. : Status of Non-Destructive Inspection Techniques with Special Reference to Welding Defects, Significance of defects in welded structure, Univ. of Tokyo Press., (1974), 9

4) Herr, J.C. and G.L. Marsh : NDT Reliability and Human Factor, Mat. Evaluation, Dec. (1978), 41

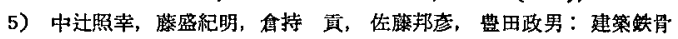

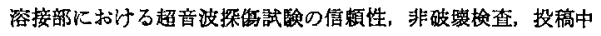

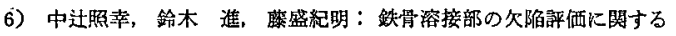
研究 (その 3), 日本建築学会潇概, 54-9 (1979)，1095

7）確率論の芯用に関しては，例之ば，板坦，岡村：強度の梳計的取 扱い，培風館 (1979) 